\title{
A comparative evaluation of effect of carbofuran 5G, chlorpyrifos 20Ec and chilli pepper aqueous extract on the growth, fruit yield and control of Podagrica uniformis of okra (Abelmoschus esculentus L. moench) in Enugu, Southeastern Nigeria
}

\author{
Awere S. U.* and Nkollo, R. N. \\ Department of Agronomy and Ecological Management, Enugu State University of Science \\ and Technology, Enugu Nigeria. \\ ${ }^{*}$ Corresponding author. Email: aweresu@yahoo.com
}

Copyright @ 2019 Awere and Nkollo. This article remains permanently open access under the terms of the Creative Commons Attribution License 4.0, which permits unrestricted use, distribution, and reproduction in any medium, provided the original work is properly cited.

Received 8th September, 2019; Accepted 5th December, 2019

\begin{abstract}
A field experiment to comparatively evaluate the effect of carbofuran 5G, chlorpyrifos 20Ec and chilli pepper aqueous extract on the growth, yield and control of insect pest of okra (Abelmoschus esculentus L. Moench) was carried out at the Teaching and Research Farm of Faculty of Agriculture and Natural Resources Management, Enugu State University of Science and Technology, Enugu, southeastern Nigeria during the 2017 rainy season between the months of April and October. The experimental design was randomized complete block (RCB) with four (4) treatments replicated five (5) times. Parameters assessed were plant height $(\mathrm{cm})$, number of feeding holes created by leaf beetles (Podagrica uniformis) per plant, number of flowers per plant, number of fruits per plant, leaf area index and fruit yield $\left(\mathrm{t} \mathrm{ha}^{-1}\right)$. The result of the experiment showed a significant $(p \leq 0.05)$ treatment effect on all the parameters measured/assessed except leaf area index. Plots treated with carbofuran $5 G$ recorded highest on all the parameters assessed except number of feeding holes created by P.uniformis per plant as follows; mean plant height of $45.45 \mathrm{~cm}$, mean number of 4.20 fruits per plant, mean leaf area index of 4.18, mean number of 48.60 feeding holes created by Podagrica per plant and mean fruit yield of $1.79 \mathrm{t} \mathrm{ha}^{-1}$. The efficacy of Chilli pepper aqueous extract (bio-insecticide) in the control of a major insect pest (Podagrica uniformis), growth and yield of okra did not significantly differ from that of chlorpyrifos 20Ec (Synthetic insecticide), the use of Chilli pepper aqueous extract to okra producers in Enugu area is therefore recommend as a better substitute to synthetic insecticide.
\end{abstract}

Keywords: Bio-pesticide, insecticides, leaf beetles (Podagrica uniformis), non-bio-pesticides, okra.

\section{INTRODUCTION}

Okra (Abelmoschus esculentus, L. Moench) is a fruit vegetable produced and consumed in many ecological zones of the world mainly for its pod yield (Sajjan et al., 2002). There are three domesticated species of okra; Abelmoschus esculentus, Abelmoschus hibiscus and Abelmschus caillei. In many English-speaking countries, it is known as "lady's finger or gumbo". It belongs to the
Malvaceae family and originated from tropical Africa. It is cultivated both in the tropical, subtropical and warm temperate regions around the world. It is widely grown in Nigeria primarily for its mucilaginous content (Tindall, 2000).

Okra is a fruit vegetable crop found in abundance in the rainy season and is commonly used as food in different homes. Usually fruit picking is done because the fruit 
reaches maturity at various times and it mainly depends on the vegetative cycle which varies according to varieties (Schipper, 2000). Okra is eaten in various ways; the leaves are eaten as raw salads, the seeds may also be roasted and ground to form non-caffeinated substitute for coffee. The immature fruits are also used as vegetable, sliced and ground and used for thickening soups. It contains a lot fibre and is required for people who want to reduce their weight because it is low in calories. The fruit is an important source of vitamin and mineral elements needed for development and maintenance of healthy human body (Schipper, 2000). Fresh okra contains $2.1 \mathrm{~g}$ protein, $0.2 \mathrm{~g}$ fat, $8 \mathrm{~g}$ carbohydrate, $36 \mathrm{~g}$ calories, $1.7 \mathrm{~g}$ fibre, $175.2 \mathrm{mg}$ minerals, $232.7 \mathrm{mg}$ vitamin and $88 \mathrm{ml}$ of water per $100 \mathrm{~g}$ edible portion (Siemonsma and Kouame, 2004).

Okra thrives well on wide range of soil but performs optimally in well drained sandy loamy soil with a pH of 6 to 6.8. Okra is moderately tolerant to soil salinity and can germinate in well-drained sandy-loam (Tindall, 2000). With increasing population, okra yield per unit area increases till a certain limit beyond which resources for plant become limited and yield decrease (Weiner, 1990). That is increasing plant population, okra yield per unit area increases till a certain point where resources for plants become limited and yield decrease. Plant spacing determines the available area for plant growth to source for resources such as water, light and nutrients. Therefore, optimal plant population size is required for high yield in okra (Awere and Njoku, 2018).

The infestation of insect pests is one of the most limiting factors for accelerating yield potential of okra. The crop is prone to damage by various insect pests because various growth stages of the crop are susceptible to different insect pests and diseases (Ekamuay, 2007). The most destructive insect pests are flea beetle species (Podagrica uniformis and Podagrica sjostedti) which are responsible for heavy defoliation of which yield losses are reported in Nigeria and Ghana (Obeng-Ofori and Sachery, 2003). As a result, this important vegetable, which is becoming a major crop especially in Eastern Nigeria, is however neglected. Insect pests must be controlled to ensure good yield and marketable quality (Palada and Chang, 2003).

Many commercial growers now spray insecticides regularly, up to twice a week instead of using traditional control method of spreading wood ash to dispel insects (Adeniyi, 2008). Considering the seriousness of insect pests, a wide range of chemicals with various spray formulations have been used in controlling podagrica spp in okra (Nazrussalam et al., 2008). Podagrica spp. have constantly been observed as major insect pest of okra, infecting the leaves of the plant and have a great economic significance on the yield of the crop (Odebiyi et al., 1981). Conventional insecticides like endosulfan, dimethoate and monocrotivos at recommended doses have been used to bring down leaf beetle population, but none of them have been proved effective to reduce the insect pest infestation significantly.

Recently, many researchers have reported that Imiforce which has imidacloprid $200 \mathrm{G} / \mathrm{L} \mathrm{SL}$. as the active ingredient (ai), which is found in different formulations in the market as Gauchu 70Ws, Admire 200SL etc are very effective to combat this insect pest (Parveen et al., 2007). There is need for more researches to find out more chemicals that are proven to be effective against the pest. Therefore, the objective of this research work was to comparatively evaluate the effect of carbofuran 5G, chlorpyrifos 20Ec and chilli pepper aqueous extract on the growth, fruit yield and control of $P$. uniformis of okra (Abelmoschus esculentus L Moench) in Enugu, Southeastern Nigeria.

\section{MATERIALS AND METHODS}

\section{Study area}

The experiment was carried out at the Teaching and Research Farm, Faculty of Agriculture and Natural Resources Management, Enugu State University of Science and Technology, Enugu, Southeastern Nigeria during the 2017 rainy season between the months of April and October. The University lies between latitude $06^{0} 50^{1} \mathrm{~N}$ and longitude $07^{0} 15^{1} \mathrm{E}$, with a mean elevation of $450 \mathrm{~m}$ above sea level and an annual rainfall of 1800 to $2100 \mathrm{~mm}$. The soil is of shale parent material and is classified as typic paleudult and is sandy clay textural class (Anikwe et al., 2005).

\section{Land preparation}

The land area for the experiment was mapped out with ropes, pegs, measuring tape and cleared with cutlass. Twenty (20) flat beds were made with a traditional hoe.

\section{Experimental design}

The experiment was carried out in a randomized complete block design with four (4) treatments replicated five (5) times. The experimental area measured $10.20 \times 13.0 \mathrm{~m}$, whereas the experimental unit/plots measured $1.8 \times 1.8 \mathrm{~m}$ with $1 \mathrm{~m}$ pathway. Plant spacing was $50 \times 50 \mathrm{~cm}$. Each plot contained four (4) rows of four (4) plants each. Two seeds were planted per hole and latter thinned to one plant per hole.

\section{Preparation of chilli pepper aqueous extract}

Twenty-five grams $(25 \mathrm{~g})$ of ground chilli pepper and one hundred and twenty grams $(120 \mathrm{~g})$ of common salt $(\mathrm{NaCl})$ were mixed together and left for twelve hours (12 hours) before filtering the emulsion. The filtered emulsion was made up to sixteen (16) liters with water, kept in the refrigerator and used within fourteen (14) days (Gabriele 2000). 


\section{Treatments}

Experimental treatments involved; (i) $100 \mathrm{~kg} \mathrm{ha}^{-1}$ of Furadan 5G (Carbofuran 5G), (ii) $1 \mathrm{~L} \mathrm{ha}^{-1}$ of Termicot 20Ec (chlorpyrifos 20Ec), (iii) $500 \mathrm{~L}^{\text {ha }}{ }^{-1}$ of plant extract (chilli pepper aqueous extract) and (iv) control. NPK 20: 10: 10 at the rate of $200 \mathrm{~kg} \mathrm{ha}^{-1}$ was applied by ring method around each plant as basal treatment two weeks after planting. The experiment was kept weed free during the experiment with traditional hoe.

Carbofuran was applied once by ring method around each plant whereas chlorpyrifos $20 \mathrm{Ec}$ and chilli pepper aqueous extract were sprayed four (4) times at fourteen (14) days interval starting from twenty-one (21) days after planting.

\section{Variety and source of okra seed}

Clemson spineless variety was sourced from Molon AgroShop, Bank Avenue Enugu, Enugu State Nigeria.

\section{Data Collection}

Data were collected on plant height $(\mathrm{cm})$, number of feeding holes created by leaf beetles ( $P$. uniformis) per plant, number of flowers per plant, number of fruits per plant, leaf area index and fruit yield ( $\left.\mathrm{tha}^{-1}\right)$. Four (4) plants were sampled from the two (2) middle rows of each plot for data 60 days after planting. A measuring tape was used to measure plant height.

\section{Data analysis}

Data collected were subjected to analysis of variance for Randomize Complete Block Designs (RCBD) experiment as outline by Obi (2001) using Genstat Release 10.3DE (PC window 2012 software). Differences between treatment means were detected using fisher's least significant difference (F-LSD) as outlined by steel and Torrie (1980).

\section{RESULTS}

Effects of carbofuran 5G, chlorpyrifos 20Ec and chilli pepper aqueous extract on plant height $(\mathrm{cm})$, number of feeding holes created by P.uniformis per plant and number of flowers per plant

The result of the experiment showed a significant treatment effect on plant height, number of feeding holes created by $P$. uniformis per plant and number of flowers per plant. On plant height, plots treated with carbofuran $5 \mathrm{G}$ recorded the highest plant height of $45.45 \mathrm{~cm}$, followed by plots treated with chlorpyrifos 20Ec that recorded plant height of $39.20 \mathrm{~cm}$, plots treated with chili pepper with plant height of $30.70 \mathrm{~cm}$ and lastly, control plots recorded plant height of $30.70 \mathrm{~cm}$ respectively (Table 1). Less mean number of 48.60 feeding holes created by $P$. uniformis per plant was recorded on plots treated with chlorpyrifos $20 \mathrm{Ec}$ that recorded a mean of 106.40 feeding holes per plant, whereas plots treated with no insecticide recorded the highest mean number of 396.33 feeding holes per plant (Table 1). On the number of flowers per plant, plots treated with carbofuran recorded the highest mean number of 7.05 flowers per plant, followed by plots treated with chlorpyrifos 20Ec which recorded mean number of 5.20 flowers per plants, chilli pepper aqueous extract that recorded a mean of 4.40 flowers per plant and no insecticides with a mean of 3.40 flowers per plant respectively.

Effects of carbofuran 5G, chlorpyrifos 20Ec and chilli pepper aqueous extract on mean number of fruits per plant, leaf area index and fruit yield ( $\left.t \mathrm{ha}^{-1}\right)$

The result of the experiment showed a significant $(p \leq 0.05)$ treatment effect of carbofuran $5 \mathrm{G}$, chlorpyrifos $20 \mathrm{Ec}$ and chilli pepper aqueous extract on the mean number of fruits per plant, fruit yield $\left(t \mathrm{ha}^{-1}\right)$ whereas there was no significant treatment effect on leaf area index. On the mean number of fruits per plant, carbofuran recorded the highest mean number of 4.20 fruits per plant, followed by chilli pepper aqueous extract that had a mean of 3.25 fruits per plant, chlorpyrifos 20Ec with a mean of 2.95 fruits per plant and control with a mean of 1.50 fruits per plant respectively.

On leaf area index, carbofuran had the highest leaf area index of 4.18 , followed by chlorpyrifos $20 \mathrm{Ec}$. with a mean leaf area index of 3.24 , chilli pepper aqueous extract with a mean of 3.08 and control with a mean of 3.01 (Table 2). On fruit yield, carbofuran recorded significantly $(p \leq 0.05)$ a higher yield of $1.79 \mathrm{t} \mathrm{ha}^{-1}$, followed by chilli pepper aqueous extract that had a mean fruit yield of $1.44 \mathrm{t} \mathrm{ha}^{-1}$, chlorpyrifos with a mean fruit yield of $1.16 \mathrm{tha}-{ }^{1}$ and control with a mean fruit yield of $0.66 \mathrm{t}$ ha ${ }^{-1}$ (Table 2).

\section{DISCUSSION}

In this research work, carbofuran $5 \mathrm{G}$ and chlorpyrifos $20 \mathrm{Ec}$ as conventional synthetic insecticides served as standard that helped to comparatively evaluate the efficacy of chilli pepper aqueous extract as bio-insecticide in the production of okra. The result of the experiment showed that chlorpyrifos 20Ec. recorded a mean plant height of $39.20 \mathrm{~cm}$ that did not significantly differ from that of chilli pepper aqueous extract which had a mean plant height of 
Table1. Effect of Carbofuran 5G, Chlorpyrifos 20Ec and Chilli pepper aqueous extract on plant height, mean number of feeding holes per plant and mean number of flowers per plant.

\begin{tabular}{lccc}
\hline Treatments & $\begin{array}{c}\text { Mean plant } \\
\text { height }(\mathbf{c m})\end{array}$ & $\begin{array}{c}\text { Mean number } \\
\text { of feeding holes }\end{array}$ & $\begin{array}{c}\text { Mean number } \\
\text { of flowers/plant }\end{array}$ \\
\hline Carbofuran 5G & 45.45 & 48.60 & 7.05 \\
Chlorpyrifos 20Ec & 39.20 & 106.40 & 5.20 \\
Chilli pepper aqueous extract & 34.30 & 235.07 & 4.40 \\
No insecticide & 30.70 & 396.33 & 3.40 \\
F-LSD 0.05 & $9.10^{*}$ & $156.00^{*}$ & $1.33^{*}$ \\
\hline
\end{tabular}

Table 2. Effect of Carbofuran 5G, Chlorpyrifos 20Ec and chilli pepper aqueous extract on the number of fruits per plant, leaf area index and fruit yield (ton ha- ${ }^{1}$ ).

\begin{tabular}{lccc}
\hline Treatments & $\begin{array}{c}\text { Mean number } \\
\text { of fruits/ plant }\end{array}$ & $\begin{array}{c}\text { Mean leaf } \\
\text { area index }\end{array}$ & $\begin{array}{c}\text { Mean fruit } \\
\text { yield (t ha- }{ }^{-1} \text { ) }\end{array}$ \\
\hline carbfuran 5G & 4.20 & 4.18 & 1.79 \\
chlorpyrifos 20Ec & 2.95 & 3.25 & 1.16 \\
Chilli pepper aqueous extract & 3.25 & 3.08 & 1.44 \\
no insecticide & 1.50 & 3.01 & 0.66 \\
F-LSD 0.05 & $0.29^{*}$ & N.S & $0.31^{*}$ \\
\hline
\end{tabular}

$34.30 \mathrm{~cm}$. Again, on the control of $P$. uniformis, chlorpyrifos 20Ec recorded a mean of 106.40 feeding holes created by the insect pest per plant which did not significantly $(p \leq 0.05)$ differ from that of chilli pepper aqueous extract that recorded a mean of 235.07 feeding holes per plant. Furthermore, chlorpyrifos 20Ec recorded a mean of 5.20 flowers per plant that did not significantly $(p \leq 0.05)$ differ from that of aqueous chilli pepper which recorded a mean of 4.40 flowers per plant.

The result of this experiment may therefore suggest that okra farmers in Enugu whose emphasis are on reduction of plant height for easy harvest, control $P$. odagrica attack and increase flower production as a component of yield may use chilli pepper aqueous extract instead of synthetic insecticides to comply with the present demand for the use of more bio-pesticides that are more eco-friendly than synthetic ones.

The result of the experiment further showed that chilli pepper aqueous extract recorded significant $(p \leq 0.05)$ higher fruits yield than chlorpyrifos $20 \mathrm{Ec}$. A similar result was reported by Awere and Omeje, (2019) when a higher dose of $550 \mathrm{~L} \mathrm{ha-1}$ of chilli pepper aqueous extract (bio pesticide) was used to promote yield of watermelon (Citrulus lunatus).

A non-significant difference between chlorpyrifos 20Ec and chilli pepper aqueous extract revealed that chilli pepper aqueous extract was as effective as chlorpyrifos 20Ec and carbofuran (non-biopesticides) in the control of okra leaf beetle (Podagrica uniformis). The findings are in conformity with that of Suraj et al. (2015) who reported that some bio-pesticides tested such as Imidacloprid 17.8 SL,
Azadirachtin, Spinosad, Bacillus (B.t) and Beauveria bassiana, increased marketable fruit yield and control red cotton bugs (Dysdercus Koenigii F) and fruit borers (Helicoverpa armigera) of okra effectively. In the same way, Pandey and Tiwari (2011) and Fakhri and Murad (2002) reported that neem based formulations are highly effective against both nymphs and adults of red cotton bug which is also regarded as insect pest of okra. Also, Kodandaram et al. (2008) reported that annonin 1\% Ec was found to be very toxic against red cotton bug.

Again, the same chilli pepper aqueous extract recorded a leaf area index that did not significantly differ from that of chlorpyrifos 20Ec (Table 2). This result may also suggest that okra producers/farmers who aim at increasing fruit yield and also produce okra plants that can form enough canopy to protect soil surface from the impact of rain drops that may cause soil erosion should apply chilli pepper aqueous extract, since this bio-insecticide does not pollute environment or produce residues that may harm okra consumers.

\section{Conclusion and recommendation}

Since the result of this research work revealed that the efficacy of chilli pepper aqueous extract (bio-insecticide) in the control of a major insect pest $(P$. uniformis), growth and yield of okra did not significantly differ from that of chlorpyrifos 20Ec (Synthetic insecticide), the use of chilli pepper aqueous extract to okra produces in Enugu area is therefore recommend as a better substitute to synthetic 
insecticide. This bio-insecticide (chilli pepper aqueous extract), apart from being effective in the control of insect pests and improving growth and yield of okra plants, it is eco-friendly. That is, it does not pollute the environment or have residual effect on the consumers of the crop.

\section{CONFLICT OF INTEREST}

Authors declare that they have no conflict of interest.

\section{REFERENCES}

Adeniyi, O. B. (2008). Chemical control in vegetable production in Kaduna State Nigeria.Continental Journal of Agricultural Economics, 2, 38-43.

Anikwe, M. A. N., Onyia, V. N, Ngwu, O. E., \& Mba, C. N. (2005). A text book on Ecophysiology and cultivation practices of arable crop. New generation ventures limited Enugu, Southeastern Nigeria p. 71.

Awere, S. U., \& Omeje, T. E. (2019). Effect of Different Rates of Insecticide and Fungicide Combinations on the growth and yield of Watermelon [Citrullus lunatus] In Enugu Area, Southeastern Nigeria. Journal of Experimental Research, 17(2), 38-44.

Awere, S. U., \& Njoku, C. L. (2018). Evaluation of effect of insecticide (3G/L of Abamectinet $15 \mathrm{G} / \mathrm{L}$ of Acetamprid Ec.) and plant spacing on the control of Podagrica spp; growth and yield of okra (Abelmoschus esculentus) in Enugu area of southeastern Nigeria. International Journal of Agriculture and Rural Development, 2(1), 3319-3323.

Ekamuay, P. (2007). A text book on Plant diseases and insect pests of economic crops. Amarin printing and publishing $\mathrm{CO}$. Itd Bangkok, Thailand. p. 379.

Fakhri, M., \& Murad, N. (2002). Effect of ecofriendly insecticide on the reproductive biology of Dysdercus koenigii Fabr. (Hemiptera: Pyrrhocoridae), a pest of agricultural crop. Journal of Entomological Research, 26(2), 117-124.

Gabriele, S. (2000). Natural Crop protection in the tropics: Letting information come to life. Margraf Verlag.

Kodandaram, M. H., Thakur, N. A., \& Shylesha, A. N. (2008). Toxicity and morphogenetic effects of different botanicals on red cotton bug Dysdercus koenigii Fab. (Hemiptera: Pyrrhocoridae) in North Eastern Hill (NEH) region of India. Journal of Biopesticides, 1(2), 187-189.

Nazrussalam, A. M. S, Haldar, A., \& Tufail, A. (2008). Efficacy of muitineem and NSKE with insecticide for management of Amarasca biguttula and Earias vietella on Okra. Annual Plant Protection Science, 16(1), 17-20.
Obeng-oferi, D., \& Sachery, J. (2003). Field evaluation of insecticide for insect pests of okra (Abelmoschus esculentus) in Ghana. Ethiopian Journal of Science, 26,146-150.

Obi, I. U. (2001). Introduction to factorial Experiment for Agricultural, biological and social sciences Research (2nd Edition).

Odebiyi, J. A., Osisanya, E., \& Tayo, T. O. (1981). Assessment of damage caused by the leaf-eating beetles, Podagrica spp. on okra in Southwestern Nigeria. African Journal of Agricultural Sciences, 8, 103-112.

Palada, M. C., \& Chang, L. C. (2003). Suggested cultural practice for vegetables. AVRDC Publication, 3,.552.

Pandey, J. P., \& Tiwari, R. K. (2011). Neem based insecticides interaction with development and fecundity of red cotton bug (Dysdercus cingulatus Fab.). International Journal of Agricultural Research, 6(4), 335-346.

Parveen, K. S., Sajan, A. S., Patil, R. K., Dharmatti, P. R., \& Kurdikel, M. B. (2007). Influence of seed treatments and foliar spray with insecticide and neem on the growth and yield of okra. Karnataka Journal of Agricultural Sciences, 20(2), 388390.

Sajjan, A. S., Shekhargouda, M., \& Badanur, V. P. (2002). Influence of date of sowing, spacing and levels of nitrogen on yield attributes and seed yield in okra. Karnataka Journal of Agricultural Sciences, 15(2), 267-274.

Schipper, R. R. (2000). Africa indigenous vegetable in overview of the cultivated species. Chattan U.K, Natural Resource Institution Capeu Technical Centre for Agriculture and Rural Co-operation.

Siemonsma, J. S., \& Kouame, C. (2004). Vegetable plant resources of Tropical Africa (2). Prota foundation, Wageningen, Netherlands. Pp. 21-29.

Steel, R. G. D., \& Torrie, J. H (1980). Principles and procedure of statistics; A Biometrical Approach, (Second edition), McGraw Hill Inc. New York. p. 633.

Suraj, S., Sandip, P., \& Arunava, S. (2015). Evaluation of biopesticides against red cotton bug and fruit borer of okra. The Bioscan, 10(2), 601-604.

Tindall, H. D. (2000). A textbook on vegetables in the tropics (1st edition). McMillan Publishers. p. 533.

Weiner, J. (1990). A textbook on Agro ecology. Published by MC Graw co. Inc. New York. Rosset (eds). p. 215. 